\title{
Binding of Chemotactic Collagen-Derived Peptides to Fibroblasts
}

\author{
THE RELATIONSHIP TO FIBROBLAST CHEMOTAXIS
}

\author{
Thomas M. Chiang, Arnold E. Postlethwaite, Edwin H. Beachey, \\ JEROME M. SEYER, and ANDREW H. KANG, Veterans Administration Hospital and \\ the Departments of Biochemistry, Medicine, and Microbiology, University of \\ Tennessee Center for the Health Sciences, Memphis, Tennessee 38104
}

\begin{abstract}
A B S T RACT We previously showed that collagen, $\alpha$-chains, and collagen-derived peptide fragments induce chemotactic migration of human fibroblasts in vitro. We now describe biochemical and immunological evidence showing there are binding sites for collagen peptides on fibroblast membranes.

By the use of ${ }^{14} \mathrm{C}$-labeled $\alpha \mathrm{l}(\mathrm{I})$ chain, binding to intact fibroblasts was demonstrated. The process was reversible, and time- and fibroblast concentrationdependent. Scatchard plot analyses of the data obtained for the binding of $\alpha 1$ (I) suggested that there are $\cong 16 \times 10^{6}$ binding sites per fibroblast with an association constant of $1.1 \times 10^{7} / \mathrm{M}$ for $\alpha \mathrm{l}(\mathrm{I})$. Dissociation of the bound radioactivity and subsequent chromatographic analysis on agarose A-1.5 m revealed that the $\alpha 1$ was unaltered. The binding of ${ }^{14} \mathrm{C}$-labeled $\alpha 1$ was inhibited by each of the $\mathrm{CNBr}$ peptides derived from $\alpha 1$ chain of chick skin collagen and $\mathrm{CNBr}$ peptide mixtures of various genetic types of collagen chains.
\end{abstract}

Immunofluorescence studies with anti- $\alpha 1$ antibody showed that $\alpha 1$-treated fibroblasts exhibited strong immunofluorescence. The intensity of fluorescence was markedly diminished by prior absorption of the antibody with $\alpha 1$. The $\alpha 1$-treated cells stained with preimmune sera did not show significant fluorescence.

Dose-response curves of fibroblast chemotaxis induced by $\alpha 1$ and the binding of $\alpha 1$ by fibroblasts correlate closely. Furthermore, the potency of $\alpha 1$ $\mathrm{CNBr}$ peptides as chemotactic agents correlates with their ability to inhibit the binding of labeled $\alpha 1(\mathrm{I})$. These data suggest the hypothesis that collagen-

Dr. Postlethwaite is a Clinical Investigator for the Veterans Administration. Dr. Beachey is a Medical Investigator for the Veterans Administration.

Received for publication 10 August 1977 and in revised form 23 June 1978. derived peptides cause fibroblast chemotactic migration by acting on fibroblast membranes.

\section{INTRODUCTION}

Fibroblasts play an important role in the synthesis of new connective tissue elements at the site of tissue injury and inflammation. Several laboratories (1-5) have demonstrated that fibroblasts are capable of migrating in vitro or in vivo but the stimuli which cause migration of fibroblasts have not been thoroughly investigated. Recently, studies in our laboratories demonstrated that collagen and its constituent polypeptide chains, $\alpha 1$ and $\alpha 2$ as well as $\mathrm{CNBr}$ peptides derived from the denatured chains serve as chemotactic stimuli for fibroblast migration in vitro (6). The mechanism by which collagen and its degradation products attract fibroblasts and cause migration, however, has not been clarified.

In this study, we investigated the first step in the chemotactic response - the interaction of the chemotactic agent with the responding cell. We have employed ${ }^{14} \mathrm{C}$-labeled $\alpha 1$ chain of type I collagen to directly label fibroblast receptor sites and to study the interaction of various collagen-derived peptides with the receptors that may serve as recognition sites for the chemotactic response. Our data suggest that fibroblasts possess membrane receptor(s) for collagen and its denatured peptide chains. Immunofluorescence studies with specific anti- $\alpha 1$ antibody also support the hypothesis.

\section{METHODS}

Preparation of cultured human fibroblasts. Dermal fibroblasts obtained from punch biopsies of the skin of normal adults were grown in monolayer culture by a standard technique. Cultures were maintained in plastic Petri dishes 
$(100 \times 20 \mathrm{~mm})$ (Falcon Plastics, Div. of BioQuest, Oxnard, Calif.) in a humidified atmosphere containing $5 \% \quad \mathrm{CO}_{2}$. Eagle's minimal essential medium supplemented with nonessential amino acids, ascorbic acid $(50 \mu \mathrm{g} / \mathrm{ml}), \mathrm{NaHCO}_{3}$, Hepes (Calbiochem, La Jolla, Calif.) buffer ( $\mathrm{pH} 7.2$ ), penicillin $(100 \mathrm{U} / \mathrm{ml})$, streptomycin $(100 \mu \mathrm{g} / \mathrm{ml})$, and heatinactivated fetal calf serum $(15 \%)$ was used as maintenance medium.

Confluent monolayers of fibroblasts were routinely dispersed by pouring off the maintenance medium, washing the monolayers twice with $10 \mathrm{ml}$ of $0.015 \mathrm{M}$ phosphate/ $0.135 \mathrm{M} \mathrm{NaCl}, \mathrm{pH} 7.4$ (PBS), ${ }^{1}$ and then detaching them at room temperature with $1 \mathrm{ml}$ of $5 \mathrm{mM}$ EDTA in PBS. The cells, released within $2 \mathrm{~min}$, were collected in $10 \mathrm{ml}$ of maintenance medium, centrifuged at room temperature at 300 $g$ for $10 \mathrm{~min}$, and washed once with serum-free maintenance medium and PBS. The clumped cells were removed by low-speed centrifugation $(100 \mathrm{~g})$ for $2 \mathrm{~min}$. Fibroblasts were then resuspended to a concentration of $10^{6}$ cells $/ \mathrm{ml}$ in PBS. Trypan blue (1\% in PBS) exclusion tests showed $>95 \%$ viable cells. In all experiments, fibroblasts were obtained from cultures of 10-12 passages.

Preparation of chick skin collagen, $\alpha-1$ chains, and $\mathrm{CNBr}$ peptides. Neutral salt-soluble collagen was extracted from the skin of 3-wk-old White Leghorn chicks which has been rendered lathyritic by administration of $\beta$-aminopropionitrile (Aldrich Chemical Co., Inc., Milwaukee, Wis.) for 2 wk. Extracted collagen was purified by repeated precipitations with $\mathrm{NaCl}$ from neutral and acid solutions as described (7). Purified $\alpha$-chains were prepared by chromatography of heatdenatured collagen on carboxymethyl cellulose (7). For preparation of radiolabeled $\alpha 1$, the animals had been injected intraperitoneally with $100 \mu \mathrm{Ci}$ of $\left[{ }^{14} \mathrm{C}\right]$ glycine (sp act $=49.73$ $\mu \mathrm{Ci} / \mathrm{mmol}$, New England Nuclear, Boston, Mass.) in $1 \mathrm{ml}$ of sterile $0.9 \% \mathrm{NaCl}$ once a day for 3 days before they were killed. The specific activity of the ${ }^{14} \mathrm{C}$-labeled $\alpha 1$ chains was $8 \mathrm{Ci} / \mathrm{mol}$.

The CNBr peptides of the $\alpha 1$ chain were prepared by a combination of ion-exchange and molecular-sieve chromatography of $\mathrm{CNBr}$ digests of the $\alpha 1$ chain on various resins as described in detail elsewhere (8). Human collagens and $\mathrm{CNBr}$ peptide preparations are described elsewhere (6). All the collagen chains and their peptides were heat denatured immediately before adding to the binding assays.

Binding experiments. Assays for the binding of the ${ }^{14} \mathrm{C}$ labeled $\alpha 1$ chain to washed fibroblasts were performed in PBS containing $0.5 \%$ bovine serum albumin. The assay mixtures consisted of $25 \mu \mathrm{g}$ of heat-denatured $\left[{ }^{14} \mathrm{C}\right]$ glycine-labeled $\alpha 1$ in a final volume of $0.2 \mathrm{ml}$ containing $5 \mathrm{mM} \mathrm{CaCl}$ and various amounts of washed fibroblasts for the appropriate periods of time as indicated. In some experiments, various other $\mathrm{CNBr}$ peptides were added to the mixtures. After specified intervals, incubations were terminated by passing the mixture through a $0.65-\mu \mathrm{m}$ millipore filter which had been soaked in PBS containing $0.5 \%$ bovine serum albumin (Millipore Corp., Bedford, Mass.) under reduced pressure. The fibroblasts were washed with $10 \mathrm{ml}$ of PBS containing $0.5 \%$ bovine serum albumin (to eliminate the nonspecific binding of $\alpha 1$ chain to the container and filters) and counted in a Nuclear-Chicago scintillation counter (Nuclear Chicago, Des Plains, Ill.) with Aquasol (New England Nuclear) as solvent.

Identification of fibroblast-bound radioactivity. The bound radioactivity was dissociated from fibroblasts by soaking the filters containing the fibroblasts in $20 \mathrm{ml}$ of PBS containing $1.25 \mathrm{mg} / \mathrm{ml}$ of unlabeled $\alpha 1$ chain at $37^{\circ} \mathrm{C}$ for $1 \mathrm{~h}$ with

${ }^{1}$ Abbreviation used in this paper: $\mathrm{PBS}, 0.015 \mathrm{M}$ phosphate/ $0.135 \mathrm{M} \mathrm{NaCl}, \mathrm{pH} 7.4$. constant shaking. The dissociated material was chromatographed on agarose A 1.5m (Bio-Rad Laboratories, Richmond, Calif.) and carboxymethyl cellulose columns. The details of these procedures have been reported (9).

Preparation of antiserum against $\alpha 1$ chain and collagen. Antisera were raised in rabbits immunized with $1 \mathrm{mg} \alpha 1$ chains dissolved in $0.5 \mathrm{ml}$ of PBS and emulsified in an equal volume of complete Freund's adjuvant (Difco Laboratories, Detroit, Mich.). The details of this procedure as well as the determination of the antibody titer and specificity have been documented (9).

Immunofluorescence studies. Smears of washed fibroblasts were prepared on glass microscope slides. The dried smears were washed with PBS and fixed with $1 \%$ paraformaldehyde for $1 \mathrm{~min}$. The washed, fixed smears were treated with $1 \%$ paraformaldehyde for $1 \mathrm{~min}$. The washed, fixed smears were treated with a $1 \mathrm{mg} / \mathrm{ml}$ solution of $\alpha \mathrm{l}$ chain or collagen in PBS for $20 \mathrm{~min}$ at room temperature in a high humidity chamber. The treated smears were then washed twice with PBS, incubated with several drops of antiserum either to the $\alpha 1$ chain or to collagen for $20 \mathrm{~min}$ at room temperature, washed twice with PBS, and finally treated with a 1:10 dilution of fluorescein-conjugated goat anti-rabbit immunoglobulin (Ig) Kalkstad Laboratories, Chaska, Minn.) for $20 \mathrm{~min}$. At the end of incubation, the smears were washed twice with PBS and mounted with glass coverslips using one drop of Gelvatol (Monsanto Co., St. Louis, Mo.). The smears were examined with a fluorescence microscope (Carl Zeiss, New York).

Fibroblast chemotaxis assay. The procedure used was described in detail elsewhere (6). Briefly, fibroblast chemotaxis was assayed using blind-well modified Boyden chemotaxis chambers (Duke University Surgical Instrument Shop, Durham, N. C.) and polycarbonate filters containing $8-\mu \mathrm{m}$ pores (Wallabs, Inc., San Rafeal, Calif.). Substances being tested for chemotactic activity were dissolved in serum-free maintenance media and placed in the lower compartment of the chambers. The upper compartment contained the fibroblast suspension in maintenance media. Loaded chambers were then incubated at $37^{\circ} \mathrm{C}$ for $150 \mathrm{~min}$ in a humidified atmosphere containing $5 \% \mathrm{CO}_{2}$. At the end of the incubation period, polycarbonate filters were removed, fixed for $15 \mathrm{~s}$ in absolute ethanol, and stained with hematoxylin. Chemotactic activity was quantiated by counting nuclei of fibroblasts on the lower surface of the filters in 20 oil immersion fields $(\times 1,000)$. All samples were assayed in triplicate, and final activity was expressed as the mean $\pm \mathrm{SEM}$ of the replicates.

\section{RESULTS}

Binding of ${ }^{14} \mathrm{C}$-labeled $\alpha 1$ chain to fibroblasts. In preliminary experiments, we determined that dispersion of fibroblasts by treatment with trypsin or crude collagenase yielded inconsistent results with regard to the amount of ${ }^{14} \mathrm{C}$-labeled $\alpha 1$ binding and the chemotactic migration. The amount of binding and cell migration decreased as a function of the duration of the exposure to trypsin. The results obtained by using EDTAdispersed fibroblasts were consistent, therefore, we elected to employ EDTA-dispersed cells for the present studies. $^{2}$

\footnotetext{
${ }^{2}$ Since the completion of these studies, we have found that we could obtain comparable and reproducible results by using $0.25 \%$ trypsin, limiting exposure of the cells to trypsin for 3 $\mathrm{min}$, and by allowing "recovery" for $30 \mathrm{~min}$ at $37^{\circ} \mathrm{C}$.
} 
TABLE I

Binding of ${ }^{14} \mathrm{C}$-Labeled $\alpha 1$ to Human Dermal Fibroblasts

\begin{tabular}{ccc}
\hline \multicolumn{1}{c}{ Treatment } & $\begin{array}{c}\text { "CC-labeled } \alpha 1 \\
\text { bound }\end{array}$ & $\begin{array}{c}\text { Counts per } \\
\text { minute }\end{array}$ \\
\hline & $\%$ & \\
${ }^{14}$ C-labeled $\alpha 1,25 \mu \mathrm{g}$ & 100 & 386 \\
$+\alpha 1,25 \mu \mathrm{g}$ & 101 & 389 \\
$+\alpha 1,125 \mu \mathrm{g}$ & 73 & 282 \\
$+\alpha 1,250 \mu \mathrm{g}$ & 54 & 208 \\
$+\alpha 1,1.25 \mathrm{mg}$ & 52 & 201 \\
$+\alpha 1,2.5 \mathrm{mg}$ & 31 & 119 \\
\hline
\end{tabular}

${ }^{14} \mathrm{C}$-labeled chick skin $\alpha 1(25 \mu \mathrm{g}, \cong 2,000 \mathrm{cpm})$ was incubated with fibroblasts $\left(5 \times 10^{5}\right)$ for $30 \mathrm{~min}$ at $37^{\circ}$ with gentle shaking. In some experiments nonradioactive $\alpha 1$ was added in amounts indicated and incubation continued for an additional $30 \mathrm{~min}$. Fibroblast-bound ${ }^{14} \mathrm{C}$-labeled $\alpha 1$ was isolated by membrane filtration. The experiments were performed in dpublicate tubes. The radioactivity counts are not corrected for nonspecific binding.

Incubation of human dermal fibroblasts with ${ }^{14} \mathrm{C}$ labeled $\alpha 1$ resulted in binding (Table I). Binding was reversible; the bound radioactivity could be displaced with an excess of unlabeled $\alpha 1$ (Table I). The dissociation of the bound radioactivity by unlabeled $\alpha 1$ occurred rapidly at $37^{\circ} \mathrm{C}$ (Fig. 1). As shown in Table $\mathrm{I}$, some of the bound radioactivity could not be displaced with a 100 -fold excess of unlabeled $\alpha 1(31 \%)$. In the subsequent binding experiments, therefore, duplicate incubations were performed with and without the addition of a 100-fold excess of unlabeled $\alpha 1$, and the amount of labeled $\alpha 1$ bound to fibroblasts in the presence of 100 -fold excess of unlabeled $\alpha 1$ was considered as nonspecific binding. Each value for ${ }^{14} \mathrm{C}$-labeled $\alpha 1$ bound

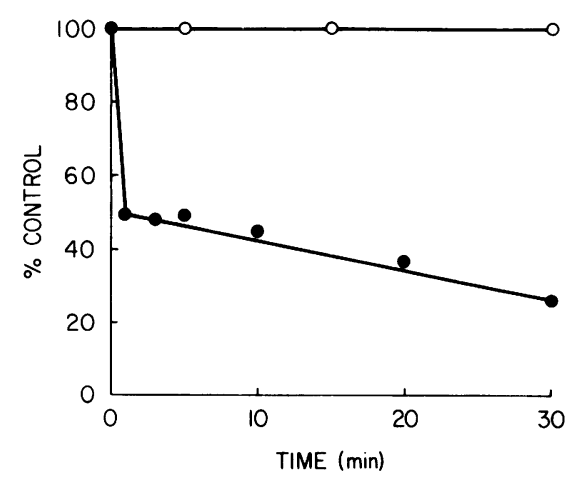

Figure 1 Dissociation of fibroblast-bound $\alpha 1$ chains. ${ }^{14} \mathrm{C}$ labeled $\alpha 1$ was preincubated with the washed fibroblasts $\left(3 \times 10^{5}\right)$ in $0.1 \mathrm{ml}$ of PBS for $20 \mathrm{~min}$ at $37^{\circ} \mathrm{C}$. At 0 time, 2.5 mg of unlabeled $\alpha 1$ dissolved in $0.2 \mathrm{ml}$ of the same buffer was added and incubated for the additional times indicated (O). To the controls was added $0.2 \mathrm{ml}$ of the same buffer only (O). Each point represents separate duplicate incubations.

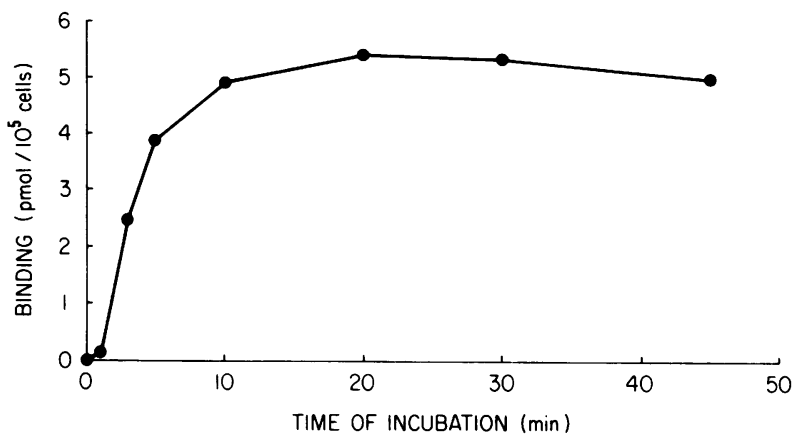

Figure 2 Time-dependent binding of ${ }^{14} \mathrm{C}$-labeled $\alpha 1$ by fibroblasts. $25 \mu \mathrm{g}$ of ${ }^{14} \mathrm{C}$-labeled $\alpha 1$ was incubated with the washed fibroblasts $\left(3 \times 10^{5}\right)$ at $37^{\circ} \mathrm{C}$. At the time indicated, fibroblasts-bound ${ }^{14} \mathrm{C}$-labeled $\alpha 1$ was isolated by membrane filtration. Each point is the mean of duplicates. All values were corrected for nonspecific binding.

by fibroblasts was corrected by subtracting the value obtained in a duplicate incubation containing excess unlabeled $\alpha 1$.

The binding of $\alpha 1$ chain to fibroblasts is a time-dependent process. The time needed to reach the maximal binding was $20 \mathrm{~min}$ at $37^{\circ} \mathrm{C}$ (Fig. 2) which is longer than the time required for a maximal binding of $\alpha 1$ chain to platelets (9). The binding of $\alpha 1$ to fibroblasts is also dependent on the concentration of fibroblasts (Fig. 3). Binding increased with the increase in the number of fibroblasts up to $5 \times 10^{5}$ cells and then leveled off in the presence of $25 \mu \mathrm{g}{ }^{14} \mathrm{C}$-labeled $\alpha 1$. In most experiments, 1 to $2 \times 10^{5}$ fibroblasts were used.

The binding of ${ }^{14} \mathrm{C}$-labeled $\alpha 1$ to fibroblasts is dependent on $\mathrm{CA}^{++}$concentration. Maximal binding was observed in the presence of $5 \mathrm{mM} \mathrm{Ca}{ }^{++}$. Higher concentrations were inhibitory (Fig. 4).

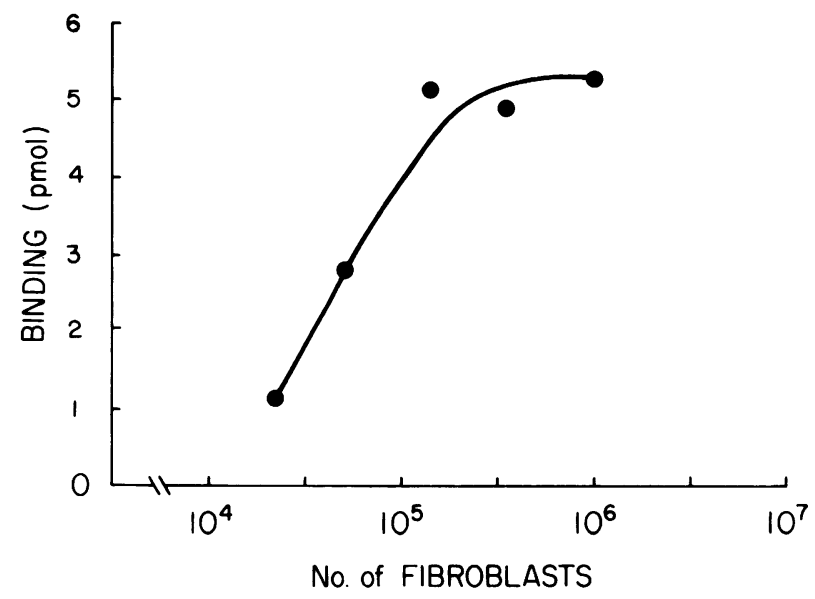

FIGURE 3 Effect of the number of fibroblasts on binding of ${ }^{14} \mathrm{C}$-labeled $\alpha 1$. Labeled $\alpha 1(25 \mu \mathrm{g})$ was incubated at $37^{\circ}$ for $20 \mathrm{~min}$ with varying numbers of fibroblasts as indicated. All values were corrected for nonspecific binding. 


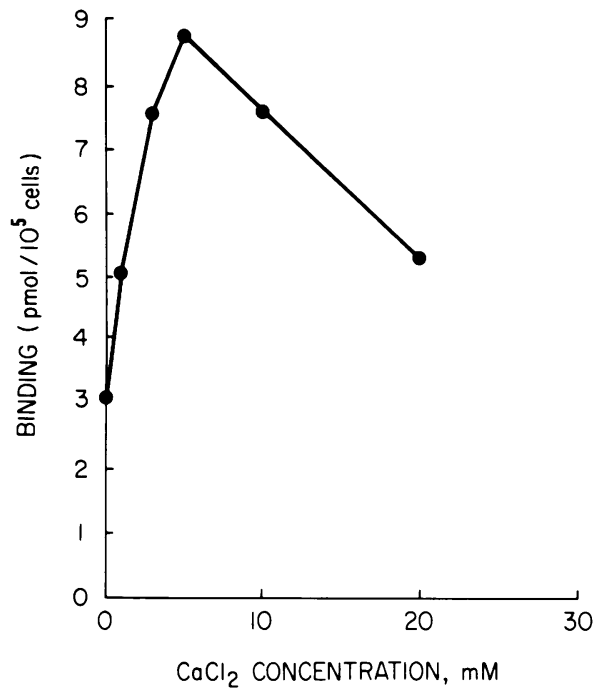

FIgURE 4 The effect of calcium ion on the binding of ${ }^{14} \mathrm{C}$ labeled $\alpha 1$ to fibroblasts. Washed fibroblasts $\left(3 \times 10^{5}\right)$ were incubated with various concentrations of $\mathrm{CaCl}_{2}$ at $37^{\circ} \mathrm{C}$ for $20 \mathrm{~min}$. All values were corrected for nonspecific binding.

Determination of association constant. To determine the average number of binding sites per fibroblasts and their affinity as measured by labeled $\alpha 1$ (I), the amount of $\alpha 1$ chain bound to fibroblasts was determined as a function of free $\alpha 1$ added to the system. The resulting data were analyzed by the method of Scatchard (10) (Fig. 5). The number of $\alpha 1$ molecules bound to fibroblasts at saturation was calculated from the intercept with the abscissa. From a number of experiments using different fibroblast sources, it was determined that there was a single population of $\cong 16$ $\times 10^{6}$ binding site per fibroblast with an association

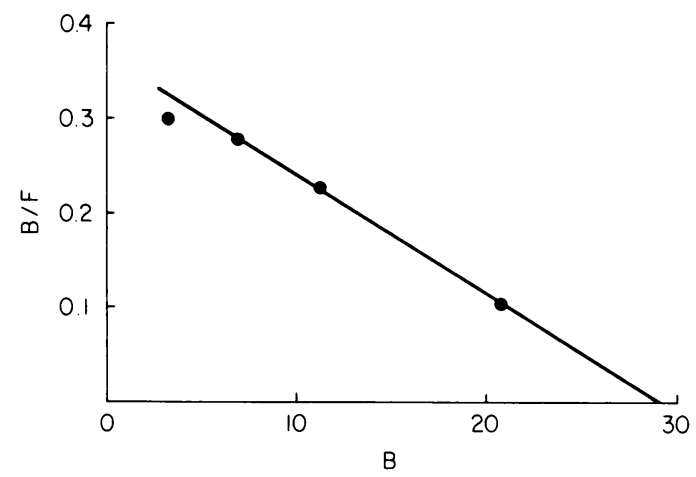

FIGURE 5 Scatchard plot. The ratio, bound:free ${ }^{14} \mathrm{C}$-labeled $\alpha 1$ is plotted as a function of bound $\alpha 1$ according to the method of Scatchard (10). B, amount of $\alpha 1$ bound (picomoles) to fibroblasts; F, amount of free $\alpha 1$ in nanomoles. The intercept with the abscissa, $29 \mathrm{pmol} / 1.1 \times 10^{6}$ fibroblasts, corresponds to an approximation of the binding capacity of fibroblast at saturation. From the Avogadro number $\left(6.02 \times 10^{23}\right)$, the number of binding sites per fibroblasts was calculated to the $\cong 16 \times 10^{6}$.

\section{TABLE II}

The Effect of Collagen, $\alpha 1, \alpha 2, \beta_{12}$, Various CNBr Peptides, and Unrelated Proteins on the Binding of ${ }^{14} \mathrm{C}$-Labeled al to Fibroblasts*

\begin{tabular}{|c|c|}
\hline Test substances & $\begin{array}{c}\text { Inhibition } \\
\text { (of specific binding) }\end{array}$ \\
\hline & $\%$ \\
\hline Control & 0 \\
\hline Lathyritic chick skin collagen & 63 \\
\hline$\alpha 1$ & 84 \\
\hline$\alpha 1-\mathrm{CB} 1$ & 18 \\
\hline$\alpha 1-\mathrm{CB} 2$ & 17 \\
\hline$\alpha 1-\mathrm{CB} 3$ & 25 \\
\hline$\alpha 1-\mathrm{CB} 4$ & 20 \\
\hline$\alpha 1-C B 5$ & 18 \\
\hline$\alpha 1-\mathrm{CB} 6$ & 22 \\
\hline$\alpha 1-\mathrm{CB} 7$ & 50 \\
\hline$\alpha 1-\mathrm{CB} 8$ & 43 \\
\hline$\alpha 2$ & 97 \\
\hline$\beta_{12}$ & 96 \\
\hline Human collagen & - \\
\hline$\alpha \mathrm{l}(\mathrm{I})$ & 86 \\
\hline$\alpha \mathrm{l}(\mathrm{I}) \mathrm{CNBr}$ peptides & 29 \\
\hline$\alpha 2$ & 91 \\
\hline$\alpha 2 \mathrm{CNBr}$ peptides & 86 \\
\hline$\alpha 1(\mathrm{II})$ & 24 \\
\hline$\alpha 1$ (II) CNBr peptides & 41 \\
\hline$\alpha 1($ III $)$ & 89 \\
\hline$\alpha 1$ (III) CNBr peptides & 80 \\
\hline Hemoglobin & 2 \\
\hline Ovalbumin & 5 \\
\hline Insulin & 5 \\
\hline
\end{tabular}

Washed fibroblasts $\left(5 \times 10^{5}\right)$ were incubated with the test substances as listed in the table for $20 \mathrm{~min}$ at $37^{\circ} \mathrm{C}$. After the addition of ${ }^{14} \mathrm{C}$-labeled $\alpha \mathrm{l}$, the mixtures were incubated at $37^{\circ} \mathrm{C}$ for another $20 \mathrm{~min}$ period. The bound $\alpha 1$ was isolated by membrane filtration. Values are expressed as the percent of control experiments. All the substances were tested 100 -fold $\mathrm{M}$ excess of ${ }^{14} \mathrm{C}$-labeled $\alpha 1$ except lathyritic chick skin collagen was tested at 50 -fold $\mathrm{M}$ excess.

constant of $1.1 \times 10^{7} / \mathrm{M}$. The association constant is about 20 times less than that determined for platelets (9).

Identity of radiolabeled material after binding to fibroblasts. Approximately $70 \%$ of the radioactivity bound to fibroblasts was eluted by extracting the fibroblasts with a 100 -fold excess of unlabeled $\alpha 1$. The dissociated material was lyophilized. A portion was dissolved in $0.01 \mathrm{M}$ Tris $1 \mathrm{M} \mathrm{CaCl}_{2}, \mathrm{pH} 7.4$, applied to a $2 \times 110-\mathrm{cm}$ column of agarose A $1.5 \mathrm{~m}$ and eluted with the same buffer. Only one radioactive peak which cochromatographed with unlabeled $\alpha 1$ chain was observed (data not shown). The recovery of the radioactivity was $\cong 95 \%$. Chromatography of a separate portion 

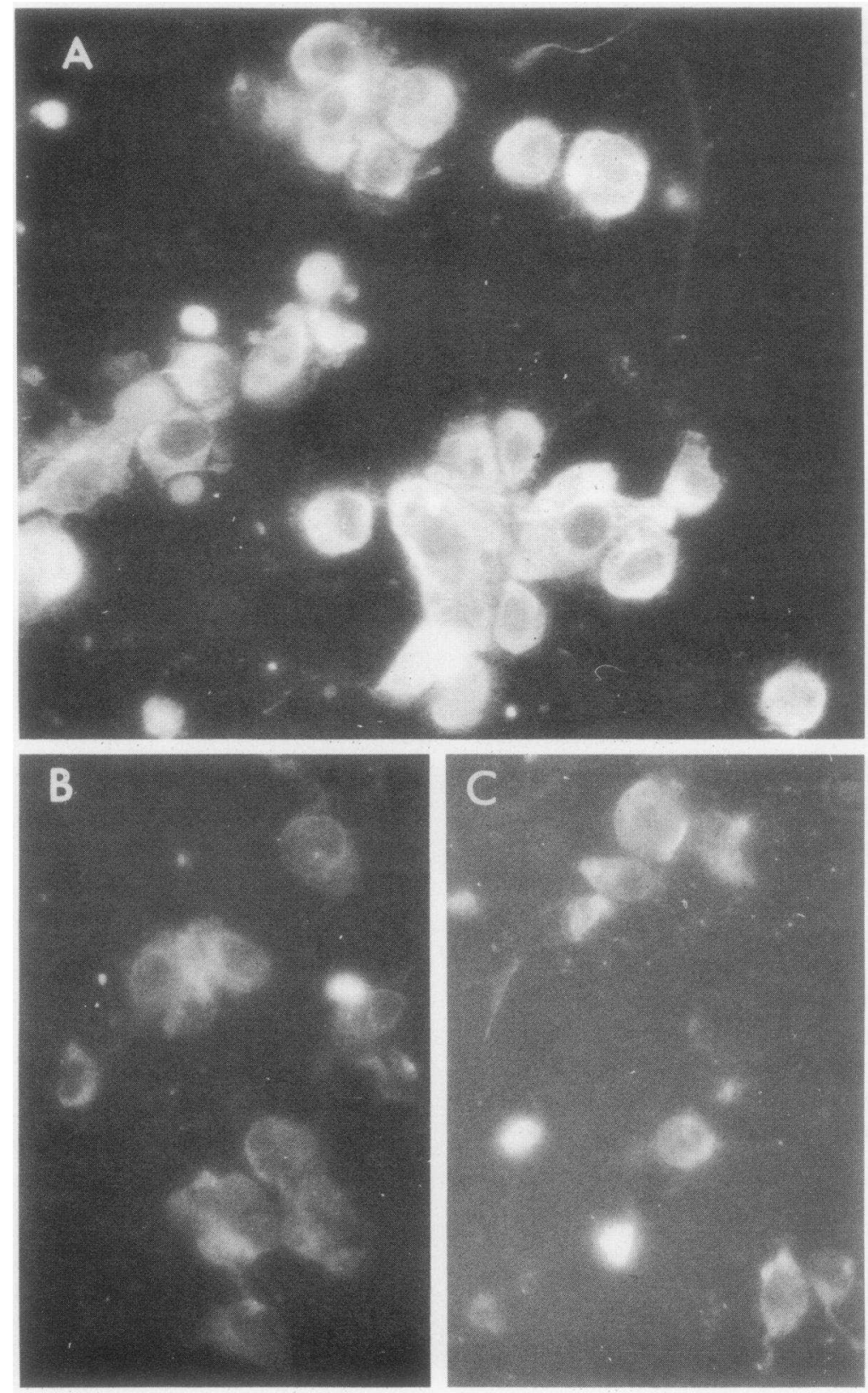

FIGURE 6 Immunofluorescence study of collagen $\alpha 1$ chain binding by fibroblasts. Dermal fibroblasts were treated with $\alpha 1$ (I) chain, washed and incubated with antiserum to $\alpha 1$ (A); preimmune rabbit serum (B); and anti- $\alpha 1$ antiserum absorbed with $\alpha 1(\mathrm{C})$; then with fluorescein-conjugated goat antirabbit IgG. Untreated fibroblasts incubated with anti- $\alpha 1$ antiserum showed weak fluorescence similar to that shown in $\mathrm{C}$.

of the displaced material on a column of carboxymethyl cellulose also yielded a single peak of radioactivity coeluting with unlabeled $\alpha 1$ (figure not shown). These results indicate that the $\alpha 1$ chain remained unaltered during the binding reaction.

Inhibition studies. In an attempt to identify the interaction site(s) between $\alpha 1$ and fibroblasts, intact col- lagen, $\alpha 1, \alpha 2, \beta_{12}$, and various $\alpha 1 \mathrm{CNBr}$ peptides were tested for their ability to inhibit binding of ${ }^{14} \mathrm{C}$-labeled $\alpha 1$ to fibroblasts. The results are presented in Table II. When tested with a 100 -fold molar excess, all of the collagen-derived peptides were capable of inhibiting the binding to some degree, although larger fragments tended to be more potent as an inhibitor than 
smaller fragments. The $\alpha 1$ and $\alpha 2$ chains of type I, $\alpha$-chains of type II and III human collagen as well as the $\mathrm{CNBr}$ peptide mixtures derived from human $\alpha$-chains produced similar results (Table II). It is of interest that the inhibitory property is not confined to the $\alpha 1-$ CB5 glycopeptide, which was shown to be specifically involved in collagen-platelet interactions (9). Several proteins unrelated to collagen had no inhibitory effect on the $\alpha 1$ binding (Table II). These results are consistent with our observation that fibroblast chemotaxis can be induced by the $\mathrm{CNBr}$ peptides as well as native types I, II, and III collagens and their $\alpha$-chains but not by the proteins unrelated to collagen (6).

Immunofluorescence studies. Further evidence that the $\alpha 1$ chain binds to fibroblasts was obtained by immunofluorescence studies. The fibroblasts treated with $\alpha 1$ followed by antiserum to $\alpha 1$ and then fluoresceinconjugated goal antirabbit IgG fluoresced intensely (Fig. 6A), as compared to the absence of fluorescence in $\alpha 1$-treated fibroblasts treated with normal rabbit serum (Fig. 6B) and to the $\alpha 1$-treated fibroblasts stained with anti- $\alpha 1$ antiserum which had been absorbed with $\alpha 1$ (Fig 6C). Untreated fibroblasts incubated with anti$\alpha 1$ antiserum showed only weak fluorescence (not shown in figure). These results support the concept that $\alpha 1$ binds to the surface of fibroblasts.

Relationship of the $\alpha 1$ binding with chemotaxis. The various concentrations of $\alpha 1$ used to induce fibroblasts chemotaxis and the amounts of $\alpha 1$ bound to intact fibroblasts at each concentration of $\alpha 1$ are depicted in Fig. 7. The dose-response curves for chemotaxis and the binding show a correlation suggesting a relationship between the two phenomena. The concentrations of $\alpha 1$ which induce fibroblast chemotaxis correlate well with those associated with binding. The relationship chemotaxis correlate well with those associated with

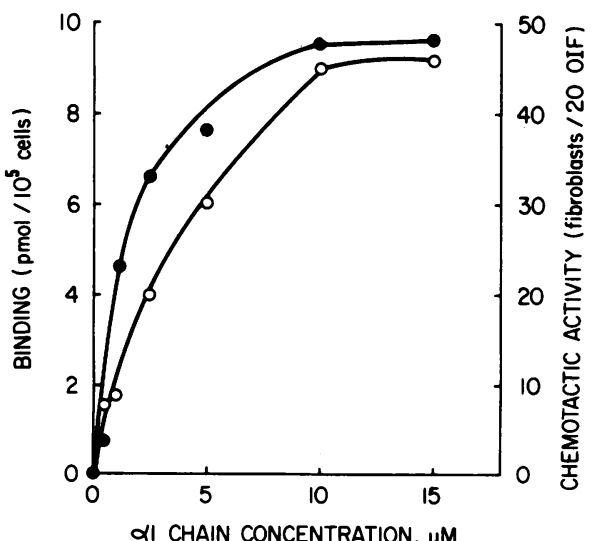

FIGURE 7 Comparison of fibroblasts chemotaxis induced by $\alpha 1(O)$ and the binding of ${ }^{14} \mathrm{C}$-labeled $\alpha 1$ by fibroblasts (O). OIF, oil immersion field.
TABLE III

Correlation of Fibroblast Chemotaxis and Inhibition of $\alpha 1$ Binding by Collagen Peptides

\begin{tabular}{ccc}
\hline $\begin{array}{c}\text { Test } \\
\text { substances }\end{array}$ & $\begin{array}{c}\text { Percentage of inhibition } \\
\text { of } \alpha 1 \text { binding }\end{array}$ & Chemotactic activity \\
\hline & $\%$ & $\begin{array}{c}\text { Fibroblasts/20 oil } \\
\text { immersion field }\end{array}$ \\
Control & 0 & $2 \pm 1$ \\
$\alpha 1-\mathrm{CB} 1$, & & \\
$30 \mu \mathrm{M}$ & 10 & $3 \pm 1$ \\
$60 \mu \mathrm{M}$ & 18 & $14 \pm 2$ \\
$\alpha 1-\mathrm{CB} 3$, & 10 & $2 \pm 1$ \\
$30 \mu \mathrm{M}$ & 22 & $50 \pm 6$ \\
$60 \mu \mathrm{M}$ & & \\
$\alpha 1-\mathrm{CB} 8$, & 12 & $12 \pm 1$ \\
$30 \mu \mathrm{M}$ & 38 & $78 \pm 6$ \\
$60 \mu \mathrm{M}$ & & \\
\hline
\end{tabular}

binding. The relationship between chemotactic property and inhibition of $\alpha 1$ binding by various $\mathrm{CNBr}$ peptides was also investigated (Table III). The largest peptide, $\alpha 1(\mathrm{I})$-CB8, with a mol wt $=24,000$ was more effective than the smallest peptide, $\alpha 1(\mathrm{I})-\mathrm{CB} 1$, with a mol wt $=1,500$ as a chemotactic stimulus (Table III) and as an inhibitory agent (Table II). The peptide, $\alpha 1$ (I)-CB3, with a mol wt $=13,000$ was intermediate in both respects (Tables II and III). These observations suggest the possible biologic significance of these binding sites in inducing fibroblast chemotaxis, as has been suggested for similar correlation between insulin binding and glucose oxidation in the isolated fat cell (11) and between binding of $N$-formylmethionyl peptides and polymorphonuclear leukocyte chemotaxis (12).

\section{DISCUSSION}

The results of biochemical and immunological studies demonstrate that binding sites for the $\alpha 1$ chain and collagen-derived peptides of collagen are present on fibroblasts. The binding of $\alpha 1$ chain to fibroblasts is reversible, and the bound ${ }^{14} \mathrm{C}$-labeled $\alpha 1$ chain can be displaced from fibroblasts by unlabeled $\alpha 1$ chain. Scatchard plot analyses indicate that fibroblasts possess a single population of binding site(s) with an association constant of $1.1 \times 10^{7} / \mathrm{M}$ for the interaction with $\alpha 1$ chain, and that at saturation an average of $16 \times 10^{6}$ molecules of $\alpha 1$ are bound per fibroblast (10). However, it is still possible that there may be an additional population of binding sites with a much higher affinity as has been reported in other systems (13-15). Because of the limitations in obtaining $\alpha 1$ chain of sufficiently high specific radioactivity by in vivo labeling of collagen, it was not possible to examine binding at much lower concentrations of $\alpha 1$ chain than used in this study.

Inhibition studies using various $\mathrm{CNBr}$ peptides in- 
dicate that virtually every one of the peptides interferes with the $\alpha 1$ binding. These results are consistent with the observation that the $\alpha 1-\mathrm{CNBr}$ peptides are active in inducing fibroblast chemotaxis (6). Furthermore, the ability of various $\mathrm{CNBr}$ peptides to inhibit $\alpha 1$ binding correlates with their chemotactic property.

A good correlation between the concentrations of $\alpha 1$ inducing fibroblast chemotaxis and those associated with the binding at the cell was obtained (Fig. 7). A similar correlation has been reported for the binding of $\mathrm{N}$-formylmethionyl peptides by polymorphonuclear leukocytes and the peptide-induced monocyte chemotaxis (12). These observations strongly support the hypothesis that the collagen $\alpha 1$ chain and collagenderived peptides act on the surface of fibroblasts to initiate the complex series of events culminating in chemotactic migration of fibroblasts. The mechanisms whereby the surface interaction effects the cell migration are not understood at present but are under investigation in our laboratory.

A comment should be made pertaining to the ability of cells involved in the secretion of collagen to respond chemotactically to exogenous collagen peptides. In normal connective tissue, collagen fibers are formed in close association with mucopolysaccharides which may serve to mask the collagen and prevent interaction with and chemotaxis of fibroblasts. At sites of tissue damage and inflammation the collagen fibers may become unmasked by the action of various lysosomal glycosidases and hydrolases and the collagen itself may be degraded by specific collagenases. Lysosomal enzymes able to digest mucopolysaccharides and proteins have been shown to reside in human neutrophils (16), and specific collagenases that are able to digest collagen fibrils have been demonstrated in neutrophils and in sites of inflammation $(17,18)$. The cleavage of collagen by a specific collagenase renders the molecules susceptible to further denaturation at physiologic ionic strength, $\mathrm{pH}$, and body temperature and the denatured molecules become susceptible to further degradation by nonspecific proteases (19). Our results obtained in this study suggest the possibility that such degradation products of collagen in inflammed tissues may serve as chemotactic stimuli for tissue fibroblasts.

\section{ACKNOWLEDGMENTS}

The authors gratefully acknowledge the expert technical assistance of Mrs. Debbie Huyghebaert.

These studies were conducted under research grants from the Veterans Administration and supported in part by research grants AI10085, AI13550, AM16506 and HL20114 from the U. S. Public Health Service.

\section{REFERENCES}

1. Abercrombie, M., J. E. M. Heaysman, and S. M. Pergrum. 1971. The locomotion of fibroblasts in culture. IV. Electron microscopy of the leading lamella. Exp. Cell Res. 67: 359-367.

2. Goldman, R. D. 1971. The role of three cytoplasmic fibers in BHK-21 cell motility. I. Microtubules and the effects of colchicine. J. Cell Biol. 51: 752-762.

3. Baum, J. L. 1971. Source of the fibroblast in central corneal wound healing. Arch. Ophthalmol. 85: 473-477.

4. Harris, A., and G. Dunn. Centripetal transport of attached particles on both surfaces of moving fibroblasts. Exp. Cell Res. 72: 519-522.

5. Postlethwaite, A. E., R. Synderman, and A. H. Kang. 1976. The chemotactic attraction of human fibroblasts to a lymphocyte-derived factor.J. Exp. Med. 144: 1188-1203.

6. Postlethwaite, A. E., J. M. Seyer, and A. H. Kang. 1978. Chemotactic attraction of human fibroblasts to collagen: chemotactic attraction of human fibroblasts to type I, II and III collagens and collagen-derived peptides. Proc. Natl. Sci. U. S. A. 75: 871-875.

7. Kang, A. H., K. A. Piez, and J. Gross. 1969. Characterization of the $\alpha$ chains of chick skin collagen and the nature of the $\mathrm{NH}_{2}$-terminal cross-link region. Biochemistry. 8: 3648-3655.

8. Kang, A. H., K. A. Piez, and J. Gross. 1969. Characterization of the cyanogen bromide peptides from the $\alpha$ l chain of chick skin collagen. Biochemistry. 8: 1506-1514.

9. Chiang, T. M., E. H. Beachey, and A. H. Kang. 1977. Binding of collagen $\alpha 1$ chains to human platelets. J. Clin. Invest. 59: 405-411.

10. Scatchard, G. 1949. The attractions of protein molecules and ions. Ann. N. Y. Acad. Sci. 51: 660-672.

11. Olefsky, J. M. 1976. The effects of spontaneous obesity on insulin binding, glucose transport, and glucose oxidation of isolated rat adipocytes. J. Clin. Invest. 57: 842851.

12. Williams, L. T., R. Snyderman, M. C. Pike, and R. J. Lofkowitz. 1977. Specific receptor sites for chemotactic peptides on human polymorphonculear leukocytes. Proc. Natl. Acad. Sci. U. S. A. 74: 1204-1208.

13. Tollefsen, D. M., J. R. Feagler, and P. W. Majerus. 1974. The binding of thrombin to the surface of human platelets. J. Biol. Chem. 249: 2646-2651.

14. Jarett, L., R. M. Smith, and S. R. Crespin. 1974. Epinephrine binding to rat adipocytes and their subcellular fractions. Endocrinology. 94: 719-729.

15. Kahn, C. R., P. Freychet, and J. Roth. 1974. Quantitative aspects of the insulin-receptor interaction in liver plasma membrane. J. Biol. Chem. 249: 2249-2257.

16. Weisman, G., R. B. Zwier, P. J. Spieler, and I. M. Goldstein. 1971. Mechanisms of lysosomal enzyme release from leukocytes exposed to immune complexes and other particles. I. Exp. Med. 134: 149s.

17. Harris, E. D., and S. M. Krane. 1974. Collagenases. $N$. Engl. J. Med. 291: 557-562.

18. Lazarus, G. S., J. R. Daniels, R. S. Brown, H. A. Bladen, and H. M. Fulmer. 1968. Degradation of collagen by a human granulocyte collagenolytic system. J. Clin. Invest. 47: 2622-2629.

19. Salsai, T., and J. Gross. 1967. Some properties of the products of reaction of tadpole collagenase with collagen. Biochemistry. 5: 518-528. 